\title{
Detection of Salmonella spp. by Conventional Bacteriology and by Quantitative Polymerase-Chain Reaction in Commercial Egg Structures
}

-Author(s)

\section{Moraes DMC \\ Duarte SC" \\ Bastos TSA' \\ Rezende CLG \\ Leandro NSM \\ Café $\mathrm{MB}^{\prime}$ \\ Stringhini $J H^{\prime}$ \\ Andrade $\mathrm{MA}^{\prime}$}

Departamento de Medicina Veterinária Preventiva, Escola de Veterinária e Zootecnia, Universidade Federal de Goiás (UFG) - Campus Samambaia, Avenida Esperança, $s / n$ Campus Universitário, Goiânia, GO 74.690900, Brasil.

" Embrapa Suínos e Aves, Rodovia BR-153, Km 110, Distrito de Tamanduá Caixa Postal: 21 CEP: 89700-000 - Concórdia - SC, Brasil.

\section{Mail Address}

Corresponding author e-mail address Thiago Souza Azeredo Bastos

Departamento de Medicina Veterinária Preventiva, Escola de Veterinária e

Zootecnia, Universidade Federal de Goiás

(UFG) - Campus Samambaia, Avenida

Esperança, s/n, Campus Universitário -

Goiânia/GO - Brasil - 74.690-900.

Phone: (55 62) 99060805

Email: tsabvet@gmail.com

\section{- Keywords}

qPCR, eggshells, albumen, yolk.

\section{ABSTRACT}

Conventional bacteriology techniques and quantitative polymerasechain reaction (qPCR) were applied to the eggshell, albumen, and yolk of washed and unwashed commercial white and brown eggs, to detect Salmonella spp. Pooled samples of eggshells, albumen, and yolk of white and brown eggs were collected at the poultry house and at the egg-storage room. Salmonella spp. was detected by conventional bacteriology in $5.4 \%$ (21/387) of analyzed samples and in 16\% (68/387) by qPCR. In the 114 unwashed white eggs samples of eggshell, albumen and yolk, the bacterium was identified in $2.6 \%$ of the eggs (3/114) by conventional bacteriology and in $13.2 \%(15 / 114)$ by qPCR. In the 90 samples of washed eggs, 6.7\% (6/90) were contaminated as detected by conventional bacteriology and $10.0 \%$ (9/90) by qPCR. In the 81 samples of unwashed brown eggs, Salmonella spp. was detected in $6.1 \%$ of the eggs $(5 / 81)$ by conventional bacteriology and $27.2 \%(22 / 81)$ by qPCR. In the 102 samples of brown washed eggs, 6.9\% (7/102) where positive by conventional bacteriology and $35.3 \%(16 / 102)$ by qPCR. All samples detected as positive by conventional bacteriology were also positive by qPCR. Salmonella Agona represented 18.2\% (4/22) of identified serovars, Salmonella enterica subs. enterica O: $4.518 .2 \%$ (4/22), Salmonella Schwarzengrund 18.2\% (4/22), Salmonella Cerro 13.6\% (3/22), Salmonella Anatum 13.6\% (3/22), Salmonella Enteritidis 9.1\% (2/22), Salmonella Johannesburg 4.5\% (1/22), and Salmonella Corvallis $4.5 \%(1 / 22)$. The gPCR method provided better detection of Salmonella spp. in commercial eggs than conventional bacteriology. The conventional egg washing and disinfection procedures are not efficient to eliminate Salmonella.

\section{INTRODUCTION}

Fresh eggs have high nutritional value, because it contains all essential amino acids and it is rich in vitamins and minerals (Nepa, 2011). In addition, it is an inexpensive protein source. The egg production industry has faced several environmental, animal welfare, and animal health challenges. Salmonella contamination stands out among animal health issues, as it may cause significant production losses and severe public health problems.

Epidemiological research has pointed the egg as a source of human contamination with Salmonella spp. in foodborne infection outbreaks. This bacterium was found to be the main agent of foodborne diseases (FBD) and during 2009, fresh eggs were considered the main cause of FDB in the United States (Cdc, 2010). In the European Union in 2008, salmonellosis was associated with food poisoning caused by the consumption of eggs and egg by-products (Efsa, 2010). In Brazil, the same scenario is observed. According to Brazilian Health Surveillance 
Moraes DMC, Duarte SC, Bastos TSA, Rezende CLG, Leandro NSM, Café MB, Stringhini JH, Andrade MA

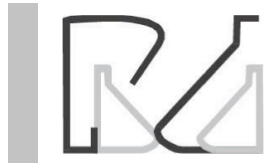

Secretariat, Salmonella spp. was the most prevalent agent in food poisoning outbreaks from 1999 to 2008 (Svs, 2008).

Eggs may be contaminated with Salmonella spp. in the reproductive tract during their formation, and immediately after lay by direct contact with contaminated fomites, such as poultry litter, nests, cages, trays, transport crates, as well as by handlers (Cox et al., 2000). The contamination of egg structures depends on the site of infection in the reproductive tract. The yolk, yolk membrane, albumen, eggshell membrane, and eggshells may be contaminated by Salmonella spp. when the ovarian follicles, infundibulum, magnum, isthmus, and shell gland, respectively, are infected (Gantois et al., 2009).

The yolk is a suitable substrate for bacterial multiplication and differently from other egg structures, it does not have mechanisms to prevent bacterial growth (Tranter \& Board, 1982). In addition of infecting the ovaries, the yolk can be infected by the penetration of Salmonella spp. through the contaminated eggshell and yolk membrane. Yolk invasion rate is affected by egg storage time and temperature (Kanashiro et al., 2002).

The albumen contains antimicrobial substances (Gantois et al., 2009). It has a high concentration of ovotransferrin, which chelates iron, inhibiting bacterial growth, as well as lysozymes, which are cationic peptides capable of interacting with the lipopolysaccharide layer (LPS) of the cell wall of Gram-negative bacteria, forming pores that allow albumin overflow into the bacterial cytoplasm (Clavijo et al., 2006).

The intact eggshell has physical barriers that prevent bacterial penetration, including the cuticle, the eggshell membrane, and a thick layer of material that separates the shell membrane from the albumen (Lunam \& Ruiz, 2000).

Chemical compounds are used to disinfect the eggs in order to reduce the number of existing microorganisms in the eggshell (Marques et al., 1994). Aragon-Alegro et al. (2005) stated that the washing process and use of disinfectants reduce the contamination risk. According to Stringhini et al. (2009), washed eggs have better eggshell bacteriological quality than unwashed eggs, even they did not detect Salmonella spp. in the eggshells analyzed in their study.

In Brazil, the Salmonella spp. survey methodology recommended by Brazilian Ministry of Agriculture is the traditional method of conventional bacteriological test (Brasil, 1997). However, this is a time-consuming and labor-intensive technique. Therefore, new
Detection of Salmonella spp. by Conventional Bacteriology and by Quantitative Polymerase-Chain Reaction in Commercial Egg Structures

pathogen-detection methodologies, especially used for foodborne infections, have been developed, and include $P C R$, which is faster and requires less labor (Sachse, 2003).

The European Committee for Standardization recommends that the PCR method should be standardized and meet some criteria, such as accuracy of analysis and diagnosis, high sensitivity, low contamination, accessible and easy-to-interpret protocols. The quantitative PCR (qPCR) assay was developed to meet those criteria, combining amplification and detection in a closed tube, thereby reducing contamination risks (Malorny et al., 2003).

In the light of the above, this study aimed at analyzing the presence of Salmonella spp. in the eggshell, yolk, and albumen of washed and unwashed brown and white commercial eggs by conventional bacteriological methods and by qPCR.

\section{MATERIAL AND METHODS}

\section{Location}

The experiment was conducted at the Bacteriology Laboratory and at the Molecular Diagnostics Laboratory of the Department of Veterinary Medicine of the School of Veterinary Medicine and Animal Science of the Federal University of Goiás, Brazil.

\section{Sampling}

Samples were collected on small, medium, and large layer farms with hens of different breeds and ages during 2012 and 2013. During the 24-month period, 68 dozens of white eggs and 61 dozens of brown eggs were randomly collected in poultry houses and the egg-storage room of the farms every two weeks.

Each collected dozen corresponded to three sample units: eggshell, albumen and yolk, totaling 387 samples. Out of the 68 dozens of analyzed white eggs, 38 were collected directly from production sheds, and were identified as unwashed eggs; and the remaining 30 dozens were collected from the egg-storage room and were identified as washed eggs. These were mechanically washed with chlorinated water, with approximately $10 \mathrm{ppm}$ free chlorine, at $35-40^{\circ} \mathrm{C}$. Out of the 61 dozens of brown eggs collected, 27 were unwashed and 34 were washed.

After an aseptic collection, eggs were placed in cardboard egg cartons (12 eggs per carton), which were identified and placed in coolers containing reusable ice packs, and directly submitted to the laboratory, where they were processed according to Brasil (2003) with some modifications. 
Moraes DMC, Duarte SC, Bastos TSA, Rezende CLG, Leandro NSM, Café MB, Stringhini JH, Andrade MA
Detection of Salmonella spp. by Conventional Bacteriology and by Quantitative Polymerase-Chain Reaction in Commercial Egg Structures

\section{Conventional bacteriological Salmonella spp. research}

At the laboratory, after sterilization of smaller diameter end of the eggs with $70 \%$ alcohol, each dozen eggs were broken. Parts of the eggshell were discarded, and the remaining eggshell, the albumen and the yolk were separated and individually placed in a sterilized container.

Each dozen eggs originated three samples: a 12-shell pool, a 12-albumen pool, and a 12-yolk pool. Samples were individually homogenized and $25 \mathrm{~g}$ of shell, $25 \mathrm{~mL}$ of yolk, and $25 \mathrm{~mL}$ of albumen were placed in an Erlenmeyer flask containing $225 \mathrm{~mL}$ of $1 \%$ peptone solution.

Samples in $1 \%$ peptone water were incubated at $37^{\circ} \mathrm{C}$ for $18-20 \mathrm{~h}$. After this period, samples were homogenized, and $1 \mathrm{~mL}$ was transferred to $9 \mathrm{~mL}$ of Selenite Cystine Broth (SC) and $1 \mathrm{~mL}$ to $10 \mathrm{~mL}$ of Rappaport Vassiliadis broth (RV), followed by incubation at $37^{\circ} \mathrm{C}$ for $24 \mathrm{~h}$. Aliquots of $2 \mathrm{~mL}$ of SC were placed in Eppendorf tubes and stored at $-20^{\circ} \mathrm{C}$ for qPCR. Using a nichrome inoculation loop, aliquots were the streaked on the surface of XLT4, Hektoen, and brilliant green agar plates, and again incubated at $37^{\circ} \mathrm{C}$ for $24 \mathrm{~h}$. Colonyforming Units (CFU) with characteristic Salmonella morphology were selected, and three to five CFU per plate were transferred to tubes containing triple sugar iron agar (TSI) and incubated at $37^{\circ} \mathrm{C}$ for $24 \mathrm{~h}$. TSI cultures suggestive of Salmonella were subjected to urease, indole production, methyl red, motility, lysine decarboxylase, Simmons citrate, and malonate tests. When the biochemical test results indicated the presence of Salmonella, the samples were subjected to serological tests with polyvalent o-antisera, and those positive were referred to the Oswaldo Cruz Foundation (FIOCRUZ)-RJ on nutrient agar for serological typing.

\section{Salmonella spp.}

Before the extraction procedure, the frozen samples in selenite cystine broth were again subjected to bacterial enrichment using $9 \mathrm{~mL}$ of selenite-cystine broth. Total DNA was isolated by boiling lysis (Santos et al., 2001). A $400 \mu \mathrm{L}$ sample was placed in a $1.5 \mathrm{~mL}$ polypropylene tube, free from DNA and RNA (Axygen). The tube containing the sample was centrifuged at $2,000 \mathrm{~g}$ for four minutes. The supernatant was discarded and suspended in $1 \mathrm{~mL}$ TE $(100 \mathrm{~mL}$ Tris/HCL $1 \mathrm{~m}+20 \mu \mathrm{L}$ EDTA $0.5 m+9,880 \mu \mathrm{L} \mathrm{H}_{2} \mathrm{O}$ ). The sample was mixed by vortexing for ten seconds and centrifuged at 2,000g for eight minutes. After discarding the supernatant, the pellet was suspended in $100 \mu \mathrm{L}$ TE. The mixture was washed, vortexed for ten seconds, and placed on a hotplate at $95^{\circ} \mathrm{C}$ for 20 minutes, aliquoted, and stored at $-20^{\circ} \mathrm{C}$ in a freezer for later use.
The qPCR assays for the detection of Salmonella spp. were performed according to Calvó et al. (2008) with some modifications. The eluates obtained from the extracted samples were used for qPCR using the TaqMan ${ }^{\circledR}\left(\right.$ Life $\left.^{\circledR}\right)$ system. A sample volume of $20 \mu \mathrm{L}$ was used, with $4.6 \mu \mathrm{L}$ of milli-Q water, $10 \mu \mathrm{L}$ of Master Mix (1x), $2 \mu \mathrm{L}$ of IPC mix (10x), $0.4 \mu \mathrm{L}$ of IPC DNA (50x) and $1 \mu \mathrm{L}$ of oligonucleotide primers (concentration $30 \mathrm{mM}$ ), and probe (concentration of $10 \mathrm{mM}$ ) adding $2 \mu \mathrm{L}$ of DNA samples. As a reaction internal control, IPC DNA was placed in one of the wells of a 96-well plate, along with an IPC reagent blocker (negative control blocked IPC, Life ${ }^{\circledR}$ ) and another with IPC DNA without blocking. Samples were tested for presence or absence of Salmonella spp. by the StepOnePlus ${ }^{\mathrm{TM}}$ qPCR System (Applied Biosystems) under the following conditions: pre-PCR at $60^{\circ} \mathrm{C}$ for 30 seconds followed by $95^{\circ} \mathrm{C}$ for 10 minutes, 40 cycles at $95^{\circ} \mathrm{C}$ for 15 seconds (denaturation step) and $60^{\circ} \mathrm{C}$ for 1 minute and $60^{\circ} \mathrm{C}$ for 30 seconds for extension step.

The TaqMan® system was used to detect Salmonella spp. by $\mathrm{qPCR}$, applying oligonucleotide primers SAL1410f5'-GGTCTGCTGTACTCCACCTTCAG-3' and SAL1494r 5'-TTGGAGATCAGTACGCCGTTCT-3' and probe SAL1441pr FAM- TTACGACGATATTCGTCCGGGTGAAGTG - TAMRA, developed by Calvó et al. (2008).

Results were analyzed using the StepOne Software v2.1 (Applied Biosystems), at 95\% confidence level.

\section{Statistical Analysis}

Results were interpreted using Binomial Distribution analysis with R Statistical Software (Core Team, 2015). The Kappa (K) coefficient was applied to analyze the consistency of the test results, using $R$ Statistical Software (Core Team, 2015), and the conventional interpretation of the values of $k$ were the following: $0.00-0.20=$ weak consistency, $0.21-0.40=$ regular, $0.41-0.60=$ moderate, $0.61-0.80=$ good, $0.81-1.00$ $=$ very good. Negative values were interpreted as 0.00 .

\section{RESULTS AND DISCUSSION}

Table 1 shows the occurrence of Salmonella spp. in different fresh egg structures according to conventional bacteriology and $\mathrm{qPCR}$ results.

Out of the 387 eggshell, albumen, and yolk samples subjected to conventional bacteriology and qPCR, 5.4\% (21/387) and 16.0\% (62/387) samples, respectively, were positive for Salmonella spp. The 21 samples positive by conventional bacteriology were also positive by qPCR. 
Table 1 - Frequency (\%) of Salmonella spp. isolated from the eggshell, albumen and yolk of unwashed white eggs (UWE), washed white eggs (WWE), unwashed brown eggs (UBE), and washed brown eggs (WBE) as determined by conventional bacteriological (CB) and $\mathrm{qPCR}$.

\begin{tabular}{|c|c|c|c|c|c|c|c|c|c|c|c|c|c|c|}
\hline \multirow[b]{2}{*}{ Samples } & \multicolumn{3}{|c|}{ UWE } & \multicolumn{3}{|c|}{ WWE } & \multicolumn{3}{|c|}{ UBE } & \multicolumn{3}{|c|}{ WBE } & \multicolumn{2}{|c|}{ Total of samples } \\
\hline & $n$ & $C B$ & qPCR & $\mathrm{n}$ & $C B$ & $\mathrm{qPCR}$ & $n$ & $C B$ & $\mathrm{qPCR}$ & $\mathrm{n}$ & $\mathrm{CB}$ & qPCR & $\begin{array}{c}C B \\
n+(\%)\end{array}$ & $\begin{array}{c}\text { qPCR } \\
n+(\%)\end{array}$ \\
\hline Shell & 38 & 1 & 9 & 30 & 1 & 3 & 27 & 1 & 10 & 34 & 3 & 7 & $6 / 129(4.7)$ & $29 / 129(22.5)$ \\
\hline Albumen & 38 & 2 & 4 & 30 & 3 & 3 & 27 & 2 & 6 & 34 & 2 & 5 & 9/129(7) & $18 / 129(14.0)$ \\
\hline Yolk & 38 & 0 & 2 & 30 & 2 & 3 & 27 & 2 & 6 & 34 & 2 & 4 & $6 / 129(4.7)$ & $15 / 129(11.6)$ \\
\hline Total (\%) & 114 & 2.6 & 13.1 & 90 & 6.7 & 10.0 & 81 & 6.1 & 27.2 & 102 & 6.9 & 35.3 & $21 / 387(5.4)$ & $62 / 387(16.0)$ \\
\hline
\end{tabular}

The $\mathrm{qPCR}$ technique detected a higher number of Salmonella spp. positive samples than conventional bacteriology in all types of samples (Table 1). The rates determined by both methods in the present study are higher than those described by Chemaly et al. (2009) in France, who detected Salmonella spp. by conventional bacteriology in $1.05 \%$ of the shells of eggs collected on 28 farms known to be positive for this bacterium. On the other hand, the obtained rates are close to the $3.8 \%$ determined in farm eggs and the $5.5 \%$ in eggs from grocery shops by Singh et al. (2010) using conventional bacteriology.

According to the qPCR results, shown in Table 1, the eggshells presented the highest contamination, with $22.5 \%$ (29/129), followed by the albumen, with $14 \%(18 / 129)$, and by the yolk, with $11.6 \%(15 / 129)$. Eggshells may be contaminated with bacteria by horizontal transmission, during egg passage through the cloaca, or immediately after oviposition, because during the first minutes after lay the cuticle is still immature and allows Salmonella penetration. However, for this agent to remain on the eggshell and migrate into the egg, it must overcome inherent barriers such as the cuticle, the shell membranes, and the thick layer of material that separates the shell membrane from the albumen. The bacteria can also be trapped in the membranes and be prevented from entering the egg because shell membranes function as filters and retain microorganisms (Lunam \& Ruiz, 2000). These intrinsic barriers have probably contributed to lower Salmonella spp. contamination rates of the egg contents compared with those determined in the eggshells.

Table 2 shows the distribution of serovars isolated from the shell, albumen, and yolk of washed and unwashed white and brown eggs.

Using conventional bacteriological methods, six Salmonella spp. isolates were found and identified. The isolates belonged to the following serovars: Salmonella enterica subs. enterica 0:4.5, Salmonella Schwarzengrund, Salmonella Agona, Salmonella Corvallis, Salmonella Enteritidis. The serovar Enteritidis detected in the eggshell of washed brown eggs collected from egg-storage room and handled after washing and disinfection suggests cross-contamination after lay.

As shown in Table 2, two positive samples were detected both in the eggshell and the albumen. One isolate was identified as Salmonella Agona and the other as Salmonella enterica subs. enterica 0:4.5. The agents may have possibly migrated from the eggshell

Table 2 - Salmonella serovars isolated from shell (Sh), albumen (AI) and yolk (Yo) of unwashed white egg (UWE), washed white egg (WWE), unwashed brown egg (UBE) and washed brown egg (WBE) by conventional bacteriological methods.

\begin{tabular}{|c|c|c|c|c|c|c|c|c|c|c|c|c|c|}
\hline \multirow{2}{*}{ SEROVARS } & \multicolumn{3}{|c|}{ UWE } & \multicolumn{3}{|c|}{ WWE } & \multicolumn{3}{|c|}{ UBE } & \multicolumn{3}{|c|}{ WBE } & \multirow{2}{*}{ Total } \\
\hline & Sh & $\mathrm{Al}$ & Yo & Sh & Al & Yo & Sh & Al & Yo & Sh & $\mathrm{Al}$ & Yo & \\
\hline Agona & 1 & 2 & - & - & - & - & - & - & - & - & - & - & 3 \\
\hline subs.enterica $0: 4.5$ & - & - & - & - & 1 & - & - & 1 & - & 1 & 1 & - & 4 \\
\hline Schwarzengrund & - & - & - & - & 1 & - & 1 & - & - & 1 & - & 1 & 4 \\
\hline Cerro & - & - & - & - & - & - & - & 1 & 1 & - & - & 1 & 3 \\
\hline Anatum & - & - & - & - & 1 & 1 & - & - & 1 & - & - & - & 3 \\
\hline Enteritidis & - & - & - & - & - & 1 & - & - & - & 1 & - & - & 2 \\
\hline Johannesburg & - & - & - & - & - & - & - & - & - & - & 1 & - & 1 \\
\hline Corvallis & - & - & - & 1 & - & - & - & - & - & - & - & - & 1 \\
\hline Total & 1 & 2 & 0 & 1 & 3 & 2 & 1 & 2 & 2 & 3 & 2 & 2 & 21 \\
\hline
\end{tabular}


Moraes DMC, Duarte SC, Bastos TSA, Rezende CLG, Leandro NSM, Café MB, Stringhini JH, Andrade MA
Detection of Salmonella spp. by Conventional Bacteriology and by Quantitative Polymerase-Chain Reaction in Commercial Egg Structures to the albumen, in which case, the intrinsic defenses of the eggshell and albumen were not sufficient to inhibit or inactivate the replication of the bacteria, allowing their migration from the shell to the albumen. Egg contamination may also have occurred by transovarial transmission, which occurs during egg development prior to calcium deposition for eggshell formation (Messens et al., 2005).

The greatest serovar diversity was identified in albumen (Table 2), where Salmonella Agona, Salmonella enterica subs. enterica 0:4.5, Salmonella Schwarzengrund, Salmonella Anatum, Salmonella Cerro, and Salmonella Johannesburg were detected. Out of the 21 identified isolates, one Agona, two Salmonella enterica subs. enterica 0 : 4.5, one Schwarzengrund and one Johannesburg isolates were detected only in the albumen, suggesting that the contamination occurred in the oviduct before lay. This result is supported by Gantois et al. (2008) and Gast et al. (2010), who reported the incorporation of Salmonella spp. at the time of albumen formation and preferably in the infected reproductive tract. Furthermore, according to Gantois et al. (2009), the colonization of the reproductive tract depends on bacterial genotypic and phenotypic characteristics, such as virulence, invasiveness, permanence and even on the development of mechanisms able to elude the avian immune system. The serovars identified in the albumen in the present study, Salmonella Agona and Salmonella Johannesburg, have lower capacity to survive in this structure than Salmonella Enteritidis, according to De Vylder et al. (2013).

The yolk presented the lowest detection rate of Salmonella spp. by qPCR, with $11.6 \%$ (15/129) (Table 1). In this structure, Salmonella Anatum, Salmonella Cerro, Salmonella Schwarzengrund, and Salmonella Enteritidis were identified (Table 2). The yolk is a suitable substrate for bacterial multiplication and, unlike other egg structures, it does not contain mechanisms to prevent bacterial growth (Tranter \& Board, 1982), which suggests that contamination can be derived from ovarian follicle of apparently non-infected hens. Another aspect that must be considered is that no structure was contaminated in the samples of washed or unwashed white eggs. It is noteworthy that after lay, these eggs were kept at approximately $28^{\circ} \mathrm{C}$ for $24-48$ hours. Possibly, there was not enough time to occur changes in the yolk membrane that would allow iron ion and nutrient release from the yolk to the albumen, thereby attracting microorganisms (Gantois et al., 2009). The obtained results differ from those found by Oliveira \& Silva (2000), who determined that the invasion of the yolk by Salmonella Enteritidis from the eggshell occurs in 24 hours and with greater intensity in eggs stored at room temperature.

These results support those found by Kottwitz et al. (2008), who state that commercial eggs are one of Salmonella vehicles in the human food chain, and that this microorganism is one of the most frequent and relevant etiological agents of intestinal infections.

Out of the 387 samples of the eggs analyzed by conventional bacteriology, 21 were positive for Salmonella spp. and the isolates were typed by FIOCRUZ. Most frequently isolated serovars were: Salmonella Schwarzengrund and Salmonella enterica subesp. enterica (O:4.5), with 19.0\% (4/21); followed by Salmonella Anatum, with $14.3 \%$ (3/21); Salmonella Cerro, with $14.3 \%$ (3/21); Salmonella Agona, with $14.3 \%$ (3/21); Salmonella Enteritidis, with 9.5\% (2/21); Salmonella Johannesburg, with 4.8\% (1/21); and Salmonella Corvallis, with $4.8 \%(1 / 21)$.

Serovar frequency varies according to region and country. The current results are partly different from those obtained by Shahzad et al. (2012), who determined contamination rates of eggs collected in Pakistan of $41.9 \%$ for Salmonella Enteritidis, $26.7 \%$ for Salmonella Typhimurium, $12.8 \%$ Salmonella Cerro and $8.1 \%$ Salmonella Pullorum. Chousalkar \& Roberts (2012), on the other hand, did not find any Salmonella spp. in the egg content or eggshell crush in Australia; however, six Salmonella Infantis and one Salmonella subspecies 1 D 4:12, a type of Salmonella associated with rat feces were detected in the eggshells.

In the present study, the serovar Schwarzengrund presented the highest occurrence, with 19.0\% (4/21), and was the only isolate detected in all three evaluated egg structures. According to Aarestrup et al. (2007), this serovar can cause severe cases of salmonellosis in humans. Furthermore, Chen et al. (2010) identified it as one of the main contaminants of food of avian origin in China.

Salmonella Agona was more frequent than Salmonella Enteritidis, with $18.2 \%$ and 9.1\%, respectively. Outbreaks of Salmonella Agona have been associated with different foods, including meat, cereal and fruits. All identified serovars in the present study may potentially affect human health.

The primers and probes used for $\mathrm{qPCR}$ were developed by Calvó et al. (2008) and have the bipA gene as reference. According to those researchers, other PCR assays present issues regarding inclusion and specificity. For instance, the invA gene does not 

Rezende CLG, Leandro NSM, Café MB, Stringhini JH, Andrade MA
Moraes DMC, Duarte SC, Bastos TSA,

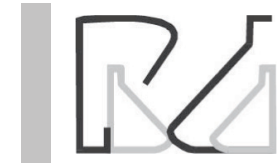

detect Salmonella Saint Paul, and the virulence genes suffer silent mutations, which means that using them as targets for the detection of Salmonella spp. can lead to false negative results. All isolated serovars were detected by $\mathrm{qPCR}$, confirming the efficacy of the method of Calvó et al. (2008), even though DNA samples were extracted from enriched selenite cystine broth and not from pre-enrichment peptone water as recommended by them.

The results obtained by the two techniques were submitted to the Kappa comparison test (Table 3).

Table 3 - Determination of the Kappa index, confidence intervals (Cl) $95 \%$ and $p$-values of positive and negative test categories for overall kappa test, considering conventional bacteriology and qPCR.

\begin{tabular}{|c|c|c|c|}
\hline & Карра & Cl 95\% & $P$ \\
\hline Positive & 0.452 & $\begin{array}{l}\text { Higher }=0.531 \\
\text { Lower }=0.373\end{array}$ & $<0.001$ \\
\hline Negative & 0.452 & $\begin{array}{l}\text { Higher }=0.531 \\
\text { Lower }=0.373\end{array}$ & $<0.001$ \\
\hline General & 0.452 & $\begin{array}{l}\text { Higher }=0.531 \\
\text { Lower }=0.373\end{array}$ & $<0.001$ \\
\hline
\end{tabular}

Bacterial culture and qPCR results were considered. According to the Kappa test, the correlation was moderate $(0.40$ to 0.59$)$, indicating that $\mathrm{qPCR}$ is a reliable tool for the quick detection of Salmonella spp. This finding is supported by researchers who reported that molecular techniques have been successfully used for Salmonella spp. research and for the identification of specific serovars (Malorny et al., 2004; Dilmaghani et al., 2011). However, Soria et al. (2012), when comparing bacteriological methods with PCR for the detection of different serovars of Salmonella spp. of artificially contaminated commercial egg samples, found poor consistency (0 to 0.19 ) in the evaluation of Kappa test.

Even though conventional bacteriology is considered the gold standard for identifying Salmonella spp. in samples of different origins, in the current study, only 21 samples were positive by conventional bacteriology out of 62 samples positive by qPCR. Therefore, 41 samples positive by $\mathrm{QPCR}$ were not isolated by bacteriology. According to Temelli et al. (2010), the marked presence of false negatives in conventional bacteriology is related to a large number of nonviable Salmonella in the samples or to a small amount of biological material. Other factors may be the overgrowth of lactose-fermenting bacteria, masking Salmonella spp. CFUs on the selective growth plates, and insufficient recovery of stressed cells.

\section{Detection of Salmonella spp. by Conventional Bacteriology and by Quantitative Polymerase-Chain Reaction in Commercial Egg Structures}

Table 4 shows the results of the binomial distribution of the results, calculated pairwise, in brown and white eggs samples, washed and unwashed, subjected to conventional bacteriological techniques and qPCR.

Table 4 - Binomial distribution of the results obtained by conventional bacteriology (CB) and by $\mathrm{qPCR}$ in unwashed and washed brown and white egg samples.

\begin{tabular}{|c|c|c|c|}
\hline Sample & $n$ & $\begin{array}{l}C B \\
n+(\%)\end{array}$ & $\begin{array}{l}q P C R \\
n+(\%)\end{array}$ \\
\hline White egg & 204 & $9 / 204(4.4)$ & 24/204(11.8)A \\
\hline Brown egg & 183 & $12 / 183(6.5)$ & $38 / 183(20.8) B$ \\
\hline $\mathrm{p}$ & - & 0.4805 & 0.02313 \\
\hline Unwashed white egg & 114 & $3 / 114(2.6)$ & 15/114(13.1) \\
\hline Washed white egg & 90 & $6 / 90(6.7)$ & $9 / 90(10.0)$ \\
\hline $\mathrm{p}$ & - & 0.2936 & 0.6339 \\
\hline Unwashed brown egg & 81 & $5 / 81(6.2)$ & $22 / 81(27.2)$ \\
\hline Washed brown egg & 102 & $7 / 102(6.9)$ & $36 / 102(35.3)$ \\
\hline$p$ & - & 1 & 0.3103 \\
\hline Unwashed white egg & 114 & $3 / 114(2.6)$ & 15/114(13.1)A \\
\hline Unwashed brown egg & 81 & $5 / 81(6.2)$ & 22/81(27.2)B \\
\hline $\mathrm{p}$ & - & 0.3885 & 0.0230 \\
\hline Washed white egg & 90 & $6 / 90(6.7)$ & 9/90(10.0)A \\
\hline Washed brown egg & 102 & 7/102(6.9) & 36/102(35.3)B \\
\hline $\mathrm{p}$ & - & 1 & 0.0007 \\
\hline
\end{tabular}

$A, B$ Means followed by different letters in the same column present different binomial distribution $(p<0.05)$.

As seen in Table 4, brown eggs, with $20.8 \%$ (38/183), were more contaminated $(p<0.05)$ than white eggs, with $11.8 \%$ (24/204), as determined by qPCR. This difference is observed both when unwashed brown eggs (27.2\%; 22/81), are compared with unwashed white eggs $(13.1 \% ; 15 / 114)$, and when washed brown eggs $(35.3 \% ; 36 / 102)$ are compared with washed white eggs $(10.0 \% ; 9 / 90)$.

The greater contamination $(p<0.05)$ of brown eggs in relation to white eggs may be related to genetic heritage. Brown layer strains seem more susceptible to Salmonella infection than white strains, as mentioned by Dunn et al. (2005). Another explanation may be the delay to start of the classification process of brown eggs, favoring Salmonella multiplication in the eggshell and its penetration into the egg. In most farms where eggs were collected, brown egg production was lower than that of white eggs, and brown eggs were classified after white eggs, at the end of the day. Another issue may be egg handling. Most white eggs were handled in automated storage rooms, where eggs are handled only at packing, after being classified. On the other hand, all washed brown eggs used in this study were manually collected in conventional sheds, packed in reusable plastic trays, and transported in trucks to the egg-storage room to be classified. 
Moraes DMC, Duarte SC, Bastos TSA, Rezende CLG, Leandro NSM, Café MB, Stringhini JH, Andrade MA

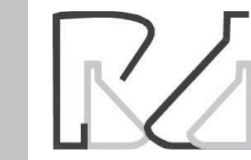

In addition, relative to the binomial distribution results shown in Table 4, there were no statistical differences between unwashed and washed white eggs or between washed and unwashed brown eggs. Therefore, it seems that the washing and sanitizing process did not interfere with the Salmonella spp. contamination levels of brown and white commercial eggs.

Table 5 shows the binomial distribution results, calculated pairwise, of the eggshells and egg contents of washed and unwashed brown and white eggs, according to conventional bacteriology and qPCR.

Table 5 - Binomial distribution of the results obtained by conventional bacteriology $(\mathrm{CB})$ and by $\mathrm{gPCR}$ in the eggshells and contents of unwashed and washed brown and white eggs.

\begin{tabular}{llll}
\hline Sample & $n$ & $\begin{array}{l}\mathrm{CB} \\
\mathrm{n}+(\%)\end{array}$ & $\begin{array}{l}\mathrm{qPCR} \\
\mathrm{n}+(\%)\end{array}$ \\
\hline Eggshell, unwashed white eggs & 38 & $1 / 38(2.6)$ & $9 / 38(23.7) \mathrm{A}$ \\
Content, unwashed white eggs & 76 & $2 / 76(2.6)$ & $6 / 76(7.9) \mathrm{B}$ \\
$\mathrm{p}$ & - & 1 & 0.0396 \\
Eggshell, washed white eggs & 30 & $1 / 30(3.3)$ & $3 / 30(10.0)$ \\
Content, washed white eggs & 60 & $5 / 60(8.3)$ & $6 / 60(10.0)$ \\
$\mathrm{p}$ & - & 0.654 & 1 \\
\hline Eggshell, unwashed brown eggs & 27 & $1 / 27(3.7)$ & $20 / 27(37.0)$ \\
Content, unwashed brown eggs & 54 & $4 / 54(7.4)$ & $12 / 54(22.2)$ \\
$\mathrm{p}$ & - & 0.8703 & 0.2509 \\
Eggshell, washed brown eggs & 34 & $3 / 34(8.8)$ & $7 / 34(20.6)$ \\
Content, washed brown eggs & 68 & $4 / 68(5.9)$ & $9 / 68(13.2)$ \\
\hline $\mathrm{p}$ & - & 0.8899 & 0.5004 \\
\hline
\end{tabular}

$A, B$ Means followed by different letters in the same column present different binomial distribution $(p<0.05)$.

As shown in Table 5, the eggshells of unwashed white eggs presented higher $(p<0.05)$ contamination than the egg contents. This finding has public health implications because, according to Braden (2006), the eggshell is considered a vehicle of Salmonella spp. contamination of the human food chain.

The eggshells of unwashed white eggs, with $23.7 \%$ (9/38), presented higher contamination $(p<0.05)$ compared with the egg content, with $7.9 \%(6 / 76)$. The unwashed white eggs were collected directly from the sheds.

Some management aspects may be responsible for eggshell contamination. Hen age influences eggshell quality, as observed by Lapao et al. (1999) and Radkowski (2002). Also, according to Shahzad et al. (2012), a higher incidence of bacteria are found in market eggs when compared with farm eggs, as a result of their contamination between the poultry farms and the retail markets.
Detection of Salmonella spp. by Conventional Bacteriology and by Quantitative Polymerase-Chain Reaction in Commercial Egg Structures

\section{CONCLUSIONS}

Washed and unwashed brown eggs showed greater contamination rates than white eggs. The eggshell of unwashed white eggs presented higher contamination rate than the other analyzed egg components. The process of washing and sanitizing commercial eggs does not seem to be an efficient method to eliminate Salmonella spp. serovars. In general, qPCR is more efficient than conventional bacteriological methods for the detection of Salmonella spp. in commercial egg structures.

\section{REFERENCES}

Aarestrup FM, Hendriksen RS, Lockett J, Gay K, Teates K, McDermott PF, White DG, Hasman $H$, Sorensen $G$, Bangtrakulnonth A. International spread of multidrug-resistant Salmonella Schwarzengrund in food products. Emerging Infectious Diseases 2007;13(5):726.

Aragon-Alegro LC, Souza KLdO, Sobrinho PdSC, Landgraf M, Destro MT. Avaliação da qualidade microbiológica de ovo integral pasteurizado produzido com e sem a etapa de lavagem no processamento. Ciência e Tecnologia de Alimentos 2005;25(3):618-622.

Braden CR. Salmonella enterica serotype Enteritidis and eggs: a national epidemic in the United States. Clinical Infectious Diseases 2006;43(4):512-517.

Brasil. Ministério da saúde. Secretaria Nacional de Vigilância sanitária de alimentos - DINAL. Padrões microbiológicos para produtos expostos à venda ou de alguma forma destinados ao consumo. Portaria n. 451 de 19 de setembro de 1997. Diário Oficial da União; Brasília, 22 de setembro de 1997; Seção 1, p. 21005-12.

Brasil. Ministério da Agricultura Pecuária e Abastecimento (MAPA). Secretaria Nacional da Defesa Agropecuária. Departamento Nacional de Defesa Animal. Coordenação Geral de Laboratório Animal. Métodos de Análises Microbiológicas para Alimentos. Brasília: MAPA; 2003. 194p.

Calvó L, Martínez-Planells A, Pardos-Bosch J, Garcia-Gil LJ. A new real-time PCR assay for the specific detection of Salmonella spp. targeting the bipA gene. Food Analytical Methods 2008;1(4):236-242.

CDC - Centers for Disease Control and Prevention. Preliminary FoodNet data on the incidence of infection with pathogens transmitted commonly through food - 10 states. MMWR - Morbidity and Mortality Weekly Report 2010;59:416-422.

Chemaly M, Huneau-Salaün A, Labbe A, Houdayer C, Petetin I, Fravalo P. Isolation of Salmonella enterica in laying-hen flocks and assessment of eggshell contamination in France. Journal of Food Protection 2009;72(10):2071-2017.

Chen MH, Wang SW, Hwang WZ, Tsai SJ, Hsih YC, Chiou CS, Tsen HY. Contamination of Salmonella Schwarzengrund cells in chicken meat from traditional marketplaces in Taiwan and comparison of their antibiograms with those of the human isolates. Poultry Science 2010;89(2):359-365.

Chousalkar KK, Roberts JR. Recovery of Salmonella from eggshell wash eggshell crush, and egg internal contents of unwashed commercial shell eggs in Australia. Poultry Science 2012;91(7):1739-1741.

Clavijo RI, Loui C, Andersen GL, Riley LW, Lu S. Identification of genes associated with survival of Salmonella enterica serovar Enteritidis in chicken egg albumen. Applied and Environmental Microbiology 2006;72(2):1055-1064. 
Core Team R. R: a language and environment for statistical computing. Vieena: R Foundation for Statistical Computing; 2015

Cox NA, Berrang ME, Cason JA. Salmonella penetration of egg shells and proliferation in broiler hatching eggs--a review. Poultry Science 2000;79(11):1571-1574

De Vylder J, Raspoet R, Dewulf J, Haesebrouck F, Ducatelle R, Van Immerseel F. Salmonella Enteritidis is superior in egg white survival compared with other Salmonella serotypes. Poultry Science 2013;92(3):842-845.

Dilmaghani M, Ahmadi M, Zahraei-Salehi T, Talebi A. Year. Detection of Salmonella enterica serovar Typhimurium from avians using multiplexPCR. Veterinary Research Forum 2012;2(3):157-165

Dunn IC, Bain M, Edmond A, Wilson PW, Joseph N, Solomon S, De Ketelaere B, De Baerdemaeker J, Schmutz M, Preisinger R. Heritability and genetic correlation of measurements derived from acoustic resonance frequency analysis; a novel method of determining eggshell quality in domestic hens. British Poultry Science 2005;46(3):280-286.

Efsa - European Food Safety Authority. Trends and sources of zoonoses and zoonotic agents and food-borne outbreaks in the European Union in 2008. EFSA Journal 2010;8:368p.

Gantois I, Ducatelle R, Pasmans F, Haesebrouck F, Gast R, Humphrey TJ, Van Immerseel F. Mechanisms of egg contamination by Salmonella Enteritidis. FEMS Microbiology Reviews 2009;33(4):718-38.

Gantois I, Eeckhaut V, Pasmans F, Haesebrouck F, Ducatelle R, Van Immerseel F. A comparative study on the pathogenesis of egg contamination by different serotypes of Salmonella. Avian Pathology 2008;37(4):399406.

Gast RK, Guraya R, Guard J, Holt PS. Multiplication of Salmonella enteritidis in egg yolks after inoculation outside, on, and inside vitelline membranes and storage at different temperatures. Journal of Food Protection 2010;73(10):1902-1906.

Kanashiro AMI, Castro AGMd, Cardoso ALSP, Tessari ENC, Jesus CAMd, Ferreira E, Souza ECAd. Isolamento de Salmonella Enteritidis em ovos comerciais, durante rastreamento de possível fonte de infecção em humanos. Higiene Alimentar 2002;16(101):76-79.

Kottwitz LB, Back A, Leão JA, Alcocer I, Karan M, Oliveira TCR. Contaminação por Salmonella spp. Em uma cadeia de produção de ovos de uma integração de postura comercial. Arquivo Brasileiro de Medicina Veterinária e Zootecnia 2008;60(2):496-8.

Lapao C, Gama LT, Soares MC. Effects of broiler breeder age and length of egg storage on albumen characteristics and hatchability. Poultry Science 1999;78(5):640-5.

Lunam CA, Ruiz J. Ultrastructural analysis of the eggshell: contribution of the individual calcified layers and the cuticle to hatchability and egg viability in broiler breeders. British Poultry Science 2000;41(5):584-592.

Malorny B, Hoorfar J, Bunge C, Helmuth R. Multicenter validation of the analytical accuracy of Salmonella PCR: towards an international standard. Applied and Environmental Microbiology 2003;69(1):290296.
Malorny B, Paccassoni E, Fach P, Bunge C, Martin A, Helmuth R. Diagnostic real-time PCR for detection of Salmonella in food. Applied and Environmental Microbiology 2004;70(12):7046-7052.

Marques D. Fundamentos básicos de incubação industrial. Amparo: Casp Indústria e Comércio; 1994.

Messens W, Grijspeerdt K, Herman L. Eggshell penetration by Salmonella: a review. World's Poultry Science Journal 2005;61(1):71-86.

Nepa - Núcleo de Estudos e Pesquisas em Alimentação. Tabela brasileira de composição de alimentos - TACO. Campinas: NEPA-UNICAMP; 2011.

Oliveira DD, Silva EN. Salmonela em ovos comerciais: ocorrência, condiçöes de armazenamento e desinfecçäo da casca. Arquivo Brasileiro de Medicina Veterinária e Zootecnia 2000;52(6):655-661.

Radkowski M. Effect of moisture and temperature on survival of Salmonella Enteritidis on shell eggs. Archiv für Geflügelkunde 2002;66(3):119123.

Sachse K. Specificity and performance of diagnostic PCR assays. PCR Detection of Microbial Pathogens 2003;216:3-29.

Santos LR, Nascimento VP, Oliveira SD de, Flores ML, Pontes AP, Ribeiro AR Salle CT, Lopes RF. Polymerase chain reaction (PCR) for the detection of Salmonella in artificially inoculated chicken meat. Revista do Instituto de Medicina Tropical de São Paulo 2001;43(5):247-250.

Shahzad A, Mahmood MS, Hussain I, Siddique F, Abbas RZ. Prevalence of salmonella species in hen eggs and egg storing-trays collected from poultry farms and marketing outlets of Faisalabad, Pakistan. Pakistan Journal of Agricultural Sciences 2012;49(4):565-568.

Singh S, Yadav AS, Singh SM, Bharti P. Prevalence of Salmonella in chicken eggs collected from poultry farms and marketing channels and their antimicrobial resistance. Food Research International 2010;43(8):20272030

Soria MA, Soria MC, Bueno DJ. A comparative study of culture methods and polymerase chain reaction for Salmonella detection in egg content. Poultry Science 2012; 91(10):2668-2676.

Stringhini MLF, Andrade MA, Mesquita AJ, Rocha TM, Rezende PM, Leandro NSM. Características bacteriológicas de ovos lavados e não lavados de granjas de produção comercial. Ciência Animal Brasileira 2009;10(4):1317-1327.

Svs- Secretaria de Vigilância em Saúde. Análise epidemiológica dos surtos de doenças transmitidas por alimentos no Brasil. Brasília: Coordenação de Vigilância das Doenças de Transmissão Hídrica e Alimentar; 2008.

Temelli S, Kahya S, Eyigor A, Carli KT. Incidence of Salmonella Enteritidis in chicken layer flocks in Turkey: Results by real-time polymerase chain reaction and International Organization for Standardization culture methods. Poultry Science 2010;89(7):1406-1410.

Tranter HS, Board RG. The inhibition of vegetative cell outgrowth and division from spores of Bacillus cereus $T$ by hen egg albumen. Journal of Applied Bacteriology 1982;52(1):67-73. 